\title{
Amplification and Direct Sequence Analysis of the 23S rRNA Gene from Thermophilic Bacteria
}

\author{
BioTechniques 30:414-420 (February 2001)
}

\author{
Ashraf Ibrahim1, Jacob \\ Hofman-Bang1, and Birgitte \\ K. Ahring1,2 \\ 1The Technical University of \\ Denmark, Lyngby, Denmark \\ and ${ }^{2}$ University of California, \\ Los Angeles, CA, USA
}

\begin{abstract}
We present a simplified and fast method to obtain high-quality sequences directly from PCRs without the traditional gel purification. We also report on an improved method to obtain sequence-quality PCR products from microorganisms that are difficult to lyse with no need for DNA extraction. The technique uses exonuclease I and shrimp alkaline phosphatase to degrade residual dNTPs and primers. Our technique is shown to work on both Gram-positive and Gram-negative bacteria.
\end{abstract}

\section{INTRODUCTION}

Gene amplification techniques integrated with direct sequence analysis protocols have established themselves as powerful tools in almost all biological disciplines. Microbiologists in particular have been blessed with the privileges of such techniques in studying microbial diversity, a concept of microbial ecology that has been greatly underestimated in traditional cultural methodology.

The ribosomal RNA genes, especially $16 \mathrm{~S}$ rRNA, have paved the way for establishing phylogenetic relationships among living organisms, whereby a well-cemented evolutionary interrelationship among all living organisms is currently shaped on a solid basis (12). Moreover, the 16S rRNA gene, with more than 9000 entries in the databases (6), has provided researchers with a con- siderable number of gene probes for the rapid identification of microorganisms (1). However, with the continual identification of new microbial taxa, the $16 \mathrm{~S}$ rRNA approach appears to be suffering from two major drawbacks. On the phylogenetic level, an overlapping of closely related microbial species seems to overshadow the potential of this gene as a reliable phylogenetic tool in the long run. More importantly, designing speciesand subspecies-specific probes on the basis of 16S rRNA is becoming a more daunting task over time. Recently, the potential of the $23 \mathrm{~S}$ rRNA gene as a phylogenetic and identification tool has started to attract the attention of more researchers (13). The inability to amplify the full gene by PCR, because of strong secondary structure and because the sequencing costs until recently have been too high, has hindered amplification and subsequent direct sequencing of the $23 \mathrm{~S}$ rRNA gene. Yet, being almost twice the size of $16 \mathrm{~S}$, the $23 \mathrm{~S}$ rRNA should statistically provide additional DNA polymorphism for probe development and more information for constructing phylogenetic trees. Commonly, 23S rRNA genes are amplified as three or even more PCR fragments $(2,9)$, thus increasing both the time and cost of the experiment. Furthermore, sequence strategies developed for the $23 \mathrm{~S}$ rRNA have relied mainly on cloning the gene, generating singlestranded templates, or direct sequencing of several partially amplified fragments.

In the present communication, we describe a protocol that allows ( $i$ ) amplification of the complete 23S rRNA gene directly from microorganisms that are difficult to lyse without the need for DNA extraction and (ii) direct fluorescent sequencing of the amplified doublestranded fragment with no need for cloning or preparation of single-stranded template. A protocol for amplification and subsequent sequencing of the $23 \mathrm{~S}$ rDNA from four different thermophilic bacteria is described to demonstrate the potential of the reported methodology.

\section{MATERIALS AND METHODS}

\section{Bacterial Strains}

Thermoanaerobacter mathranii (DSM no. 11426), Thermoanaerobacter thermohydrosulfuricus (DSM no. 567), Thermoanaerobacter ethanolicus (DSM no. 22466), and Thermoanaer-

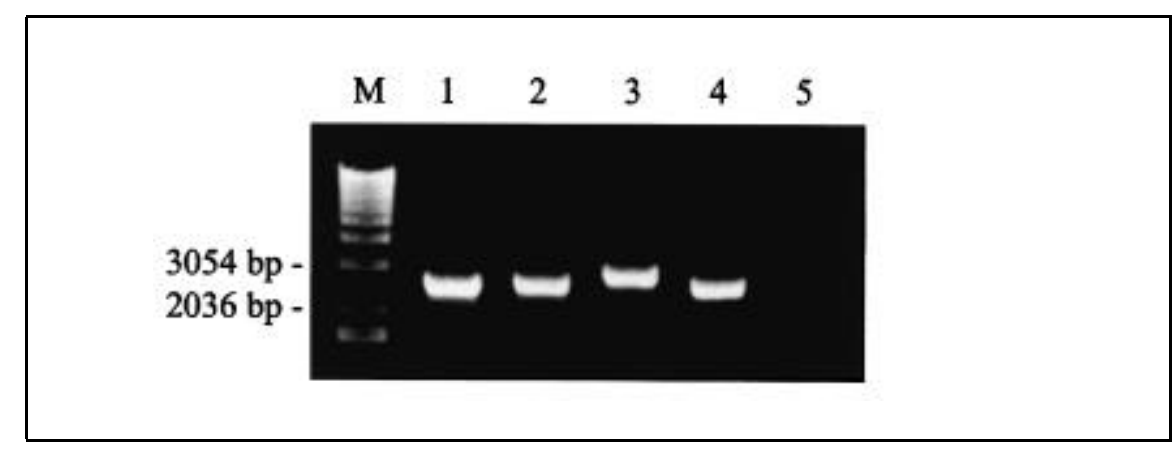

Figure 1. Amplification of the ribosomal DNA fragment encompassing the 16S-23S spacer region and the $23 S$ rDNA. Lane M, 1-kb ladder (Life Technologies, Rockville, MD, USA). Lanes $1-4,10 \%$ of the PCR product from T. mathranii, T. thermohydrosulfuricus, T. ethanolicus, and T. thermocopriae. Lane 5, negative control. 


\section{Research Report}

obacter thermocopriae (ATCC no. 51646) were obtained from our culture collection.

\section{PCR}

Frozen cultures of Thermoanaerobacter strains were first thawed to room temperature. Cells were then pelleted in a benchtop centrifuge and washed twice in $1 \mathrm{~mL}$ TE buffer. The pellet was resuspended in the same buffer, and the cell density was adjusted to $10^{6}$ cells $/ \mathrm{mL}$. One microliter of the cell suspension was added to a PCR tube containing $5 \mu \mathrm{L} 1.2 \times$ PCR buffer, prepared in our laboratory $[10 \times$ buffer consists of $500 \mathrm{mM}$ Tris- $\mathrm{HCl}, 100 \mathrm{mM}$ $\mathrm{KCl}, 20 \mathrm{mM} \mathrm{MgCl}_{2}, 10 \%$ dimethyl sulfoxide (DMSO), $10 \mathrm{mg} / \mathrm{mL}$ bovine serum albumin, and $10 \%$ betaine] and $41 \mu \mathrm{L}$ distilled water. The tubes were overlaid with $35 \mu \mathrm{L}$ mineral oil and heated in a model 9700 thermal cycler (Applied Biosystems, Foster City, CA, USA) for $30 \mathrm{~min}$. After this denaturation period, $1 \mu \mathrm{L}$ dNTPs $(10 \mathrm{mM})$ and 1 $\mu \mathrm{L}$ primers $(50 \mu \mathrm{M})$ were added, followed by $0.4 \mu \mathrm{L}$ ( $2 \mathrm{U}$ ) Taq DNA polymerase (Amersham Pharmacia Biotech, Little Chalfont, UK), keeping the thermal cycler at the high temperature. The amplification primers are listed in Table 1 and graphically outlined in Figure 3. The cycling continued with the follow ing profile: one cycle at $94^{\circ} \mathrm{C}$ for $2 \mathrm{~min}$, 10 cycles (each consisting of denaturation at $94^{\circ} \mathrm{C}$ for $1 \mathrm{~min}$, annealing at $60^{\circ} \mathrm{C}$ for $30 \mathrm{~s}$, and extension at $72^{\circ} \mathrm{C}$ for $2 \mathrm{~min}$ ), 20 cycles (each consisting of de-

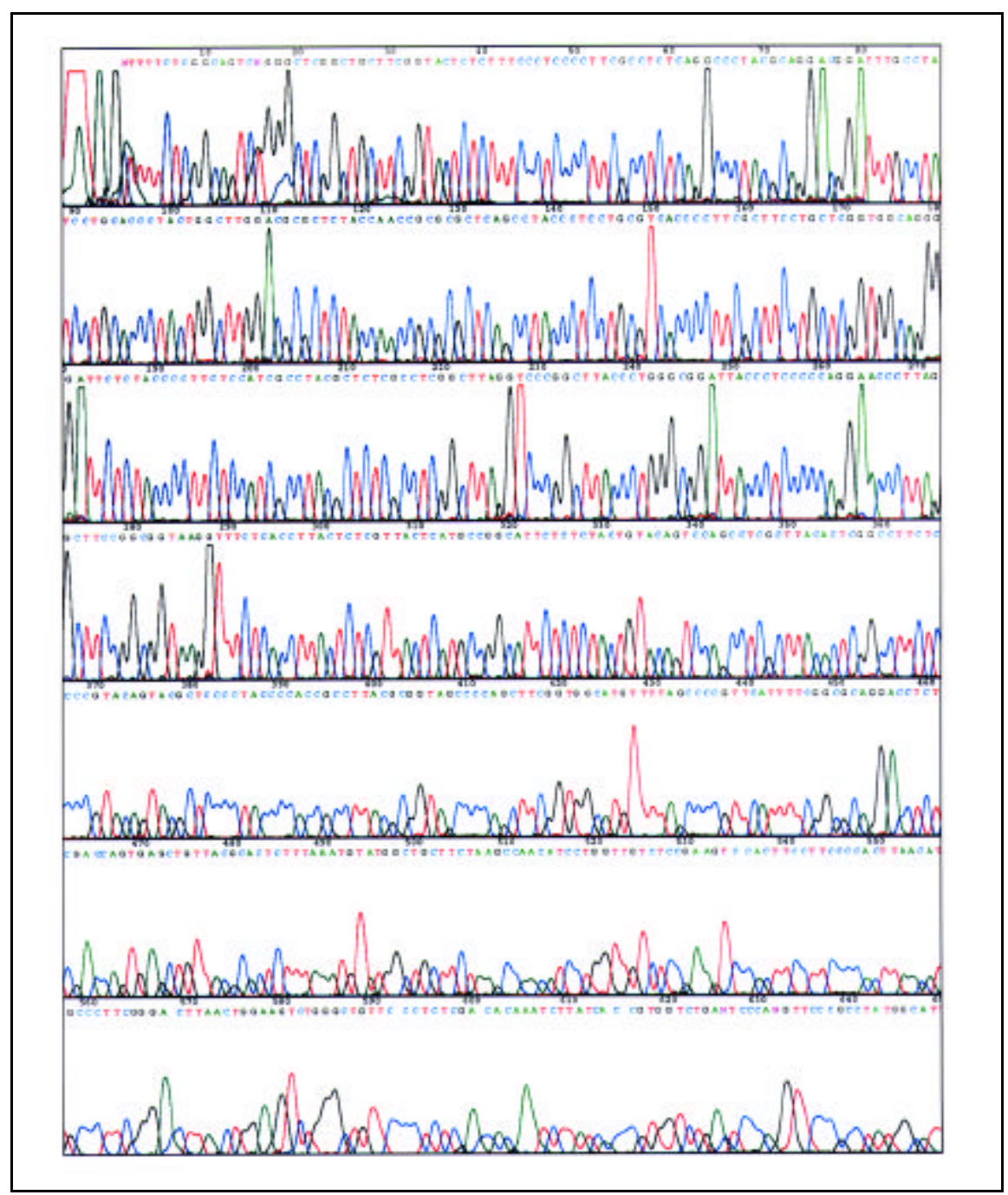

Figure 2. Electropherogram of ABI 377 automated sequencing of 23S rDNA gene from T. mathranii using primer 1091R High-quality sequence is obtained even after 650 bases with very low background. naturation at $94^{\circ} \mathrm{C}$ for $30 \mathrm{~s}$, annealing at $50^{\circ} \mathrm{C}$ for $30 \mathrm{~s}$, and extension at $72^{\circ} \mathrm{C}$ for $2 \mathrm{~min}$ ), and a final extension at $72^{\circ} \mathrm{C}$ for $7 \mathrm{~min}$. The tubes were immediately cooled to $4^{\circ} \mathrm{C}$. The PCR temperature profile is designed to specifically amplify the gene of interest with high specificity in low amounts for 10 cycles followed by amplification for 20 cycles under normal conditions (i.e., the primer 2747R used in the initial PCR has a melting temperature lower than the annealing temperature used in the PCR for the first 10 cycles). Ten percent of the PCR product was separated on a $1 \%$ agarose gel and visualized by UV light after ethidium bromide staining.

\section{Template Preparation for Sequencing}

For each sequencing reaction, $3 \mu \mathrm{L}$ PCR product were combined with 0.3 $\mu \mathrm{L}$ exonuclease I and $0.3 \mu \mathrm{L}$ shrimp alkaline phosphatase (Amersham Pharmacia Biotech) in a $1.5-\mathrm{mL}$ Eppendorf ${ }^{\circledR}$ tube. The reactants were incubated at $37^{\circ} \mathrm{C}$ for $15 \mathrm{~min}$, followed by incubation at $80^{\circ} \mathrm{C}$ for $10 \mathrm{~min}$ to inactivate any residual enzyme.

\section{Sequencing of $23 \mathrm{~S}$ rDNA}

Sequencing was carried out using the Taq Dyedeoxy Terminator Cycle Sequencing Kit (Applied Biosystems) according to the supplier's recommendations and ABI 377 automated sequencer with sequencing primers listed in Table 1 according to the protocol described in Table 2.

\section{RESULTS AND DISCUSSION}

The growth of many anaerobic microorganisms necessitates special enrichment and isolation requirements. Yet, the cell harvest is hardly adequate for further identification, even at the molecular level. Both the yield and quality of the extracted DNA are not usually suitable for PCR amplification and subsequent manipulation. Ruano et al. (8) have described a more efficient PCR amplification protocol, whereby DNA is subjected to longer denaturation period in $1.1 \times$ PCR buffer before the rest of the amplification mixture is added. In our attempt to develop a more robust ampli- 
Table 2. Sequencing Protocol

1. For each sequencing reaction, combine the following in a $200-\mu \mathrm{L}$ tube: $6 \mu \mathrm{L}$ cleaned PCR product, $0.5 \mu \mathrm{L} 1 \%$ betaine, and $4.5 \mu \mathrm{L}$ distilled water.

2. Overlay with $15 \mu \mathrm{L}$ mineral oil and incubate in a model 9700 thermal cycler (Applied Biosystems) at $94^{\circ} \mathrm{C}$ for 30 min.

3. Meanwhile, combine the following reagents (all provided in the kit except the primers) for each 10 sequence reactions: $40 \mu \mathrm{L} 5 \times$ sequencing buffer, $10 \mu \mathrm{L}$ dNTP mixture, $20 \mu \mathrm{L}$ (5 $\mu \mathrm{L}$ each dye terminator), $10 \mu \mathrm{L}$ AmpliTaq ${ }^{\circledR}$ DNA Polymerase $\mathrm{FS}$, and $10 \mu \mathrm{L}$ sequencing primer (3 pmol $/ \mu \mathrm{L})$.

4. After the 30-min denaturation cycle, add $9 \mu \mathrm{L}$ premixture prepared in Step 3. Never allow the temperature to drop below $90^{\circ} \mathrm{C}$.

5. Immediately start cycle sequencing as follows: 10 cycles each with the follow ing profile; $96^{\circ} \mathrm{C}$ for $30 \mathrm{~s}, 50^{\circ} \mathrm{C}$ for $5 \mathrm{~s}$, and $60^{\circ} \mathrm{C}$ for 6 min. 15 Cycles each with the following profile: $96^{\circ} \mathrm{C}$ for $30 \mathrm{~s}$ and $60^{\circ} \mathrm{C}$ for $4 \mathrm{~min}$.

6. Rapidly cool the tubes to $4^{\circ} \mathrm{C}$.

7. In clean 200- $\mu \mathrm{L}$ tubes combine $2 \mu \mathrm{L} 3 \mathrm{M}$ sodium acetate ( $\mathrm{pH} 5.2)$ and $50 \mu \mathrm{L}$ $95 \%$ ice-cold ethanol.

8. For each tube, add $19 \mu \mathrm{L}$ sequencing reaction (avoiding the mineral oil). Mix gently and incubate on ice for $15 \mathrm{~min}$.

9. Spin down for $15 \mathrm{~min}$ at $15000 \times \mathrm{g}$. Carefully aspirate the liquid against a light source and wash twice with $75 \%$ ice-cold ethanol.

10. Spin the tubes down in the same orientation so that the pellet is kept stable on the bottom side of the tube.

11. Aspirate any traces of ethanol and simply incubate the tubes wide open at $37^{\circ} \mathrm{C}$ for $5 \mathrm{~min}$. This is more than sufficient to get a completely dry pellet.

12. Loading buffer, denaturation step, and electrophoresis are carried out according to the sequencer model.

forward primers with superior sequence quality. In addition, less than eight sequence primers were needed to achieve the full sequence of the $23 \mathrm{~S}$ rDNA. Overall, a continuous stretch of approximately 2700 bases was obtained with the primers listed in Table 1. Note that the $16 \mathrm{~S}-23 \mathrm{~S}$ spacer region in certain bacterial species will not be possible to obtain because these loci are not linked.

Two of these primers were designed in our laboratory through the analysis of all available $23 \mathrm{~S}$ sequences in the databases $(4,6,10)$. Primer $130 \mathrm{R}$ was specifically designed to extend through the spacer region and thus enabled us to read the $5^{\prime}$ end of the gene starting from position 1. Primer 1410R closed a gap around position 1300 and eliminated the need for two additional primers. Only three forward primers were needed to resolve some sequence ambiguities.

In conclusion, the described amplification protocol, in which there is no need for any DNA extraction and regardless of the age of the microbial cultures, should facilitate the amplification of difficult templates exemplified here by the $23 \mathrm{~S}$ rRNA gene. Because of the stringent conditions applied during the amplification process, there were no coamplification products, and the quick purification protocol was used to prepare the template. With more stringent conditions during fluorescent sequencing, including the use of betaine and a long presequencing denaturation period, it was possible to directly sequence almost the full 23S rDNA with far fewer sequencing primers and longer reads. This protocol should have the potential to handle other difficult-to-sequence genes and save time and cost of partial amplification, cloning, or preparation of single-stranded templates when individual primer selections and PCR conditions are optimized.

\section{ACKNOWLEDGMENT}

This work was supported by The Danish Biotechnology Program.

\section{REFERENCES}

1.Alm, E.W., D.B. Oerther, N. Larsen, D.A. Stahl, and L. Raskin. 1996. The oligonu- cleotide probe database. Appl. Environ. Microbiol. 62:3557-3559.

2.Ash, C. and M.D. Collins. 1992. Comparative-analysis of 23S-ribosomal RNA gene-sequences of Bacillus-anthracis and emetic Bacillus-cereus determined by PCR-direct sequencing. FEMS Microbiol. Lett. 94:75-80.

3.Brosius, J., T.J. Dull, and H.F. Noller. 1980. Complete nucleotide sequence of a $23 \mathrm{~S}$ ribosomal RNA gene from Escherichia coli. Proc. Natl. Acad. Sci. USA 77:201-204.

4.De Rijk, P., E. Robbrecht, S. de Hoog, A. Caers, Y. Van de Peer, and R. De Wachter. 1999. Database on the structure of large subunit ribosomal RNA. Nucleic Acids Res. 27:174-178.

5.Lawson, V.A., D.A. McPhee, and N.J. Deacon. 1996. Elimination of sequence ambiguities by a single-step modification of a solidphase, single-stranded sequencing protocol. BioTechniques 21:356-358.

6.Maidak, B.L., J.R. Cole, C.T. Parker, Jr., G.M. Garrity, N. Larsen, B. Li, T.G. Lilburn, M.J. McCaughey et al. 1999. A new version of the RDP (Ribosomal Database Project). Nucleic Acids Res. 27:171-173.

7.Mauel, M.J., S.J. Giovannoni, and J.L. Fryer. 1999. Phylogenetic analysis of Piscirickettsia salmonis by $16 \mathrm{~S}$, internal transcribed spacer (ITS) and 23S ribosomal DNA sequencing. Dis. Aquat. Organ. 35:115-123.

8. Ruano, G., E.M. Pagliaro, T.R. Schwartz, K. Lamy, D. Messina, R.E. Gaensslen, and H.C. Lee. 1992. Heat-soaked PCR - an efficient method for DNA amplification with applications to forensic analysis. BioTechniques 13:266-274.

9.Sallen, B., A. Rajoharison, S. Desvarenne, F. Quinn, and C. Mabilat. 1996. Comparative analysis of $16 \mathrm{~S}$ and 23S rRNA sequences of Listeria species. Int. J. Syst. Bacteriol. 46:669674.

10.Stoesser, G., M.A. Tuli, R. Lopez, and P. Sterk. 1999. The EMBL Nucleotide Sequence Database. Nucleic Acids Res. 27:18-24.

11.Vancamp, G., S. Chapelle, and R. Dewachte. 1993. Amplification and sequencing of variable regions in bacterial 23S ribosomal-RNA genes with conserved primer sequences. Curr. Microbiol. 27:147-151.

12.Woese, C. 1998. The universal ancestor. Proc. Natl. Acad. Sci. USA 95:6854-6859.

13.Woo, T.H.S., L.D. Smythe, M.L. Symonds, M.A. Norris, M.F. Dohnt, and B.K.C. Patel. 1997. Rapid distinction between Leptospiral interrogans and Leptospira biflexa by PCR amplification of 23S ribosomal DNA. FEMS Microbiol. Lett. 150:9-18.

Received 20 March 2000; accepted 1 November 2000.

Address correspondence to

Professor B.K. Ahring

Department of Biotechnology

BLD 227

The Technical University of

Denmark

2800 Lyngby, Denmark

e-mail:bka@imt.dtu.dk 